\title{
Phosphites and acibenzolar-S-methyl alone and combined with fungicides for the control of biotrophic pathogens of wheat
}

\author{
Hellen Aparecida Arantes dos Santos ${ }^{1}$; Maristella Dalla Pria ${ }^{2}$; Olavo Corrêa da Silva ${ }^{3}$; Louise Larissa May-De-Mio ${ }^{3}$
}

${ }^{1}$ Federal University of Santa Catarina, Rodovia Admar Gonzaga, 1345, 84034-000, Florianópolis - SC. ${ }^{2}$ State University of Ponta Grossa, Av. Gal. Carlos de Cavalcanti, 4748, 84030-900, Ponta Grossa - PR. ${ }^{3}$ Federal University of Paraná. Rua dos Funcionários 1540, 80035-050, Curitiba - PR. Autor para correspondência: Maristella Dalla Pria (mdallapria@uepg.br)

Data de chegada: 05/07/2016. Aceito para publicação em: 16/03/2017.

$10.1590 / 0100-5405 / 2213$

\section{ABSTRACT}

Santos, H.A.A.; Dalla Pria, M.; Silva, O.C.; May-De-Mio, L. Phosphites and acibenzolar-S-methyl alone and combined with fungicides for the control of biotrophic pathogens of wheat. Summa Phytopathologica, v.44, n.2, p.132-136, 2018.

Damage to wheat crop is associated with leaf rust (Puccinia triticina) and powdery mildew (Blumeria graminis f. sp. tritici). The present study aimed to evaluate the effect of potassium phosphite and acibenzolar-S-methyl alone or associated with the fungicide epoxiconazole + pyraclostrobin on powdery mildew and leaf rust control, as well as on grain yield. The experiments were designed as randomized blocks with four replicates consisting of plots with 17 planting rows spaced at $0.17 \mathrm{~m}$, with dimensions of $2.89 \times 5.0 \mathrm{~m}$ each. Severity of powdery mildew and leaf rust was assessed in ten flag leaves and ten whole plants all over the crop season; yield was also evaluated. Severity data were used to calculate the area under the disease progress curve. There was no effect of phosphite applied alone or associated with the fungicide epoxiconazole + pyraclostrobin at different times on mildew. Acibenzolar-S-methyl controlled, on average, $70 \%$ powdery mildew. Phosphites applied alone and/or associated with the fungicide had an effect on leaf rust, reducing the severity by 59 and $62 \%$, compared to control. Applications of phosphites alone did not affect the yield components.

Keywords: Resistance induction, Blumeria graminis f. sp. tritici, Puccinia triticina, Triticum aestivum, time of application, rust and powdery mildew.

\section{RESUMO}

Santos, H.A.A.; Dalla Pria, M.; Silva, O.C.; May-De-Mio, L. Fosfitos, acibenzolar-S-methyl e fungicidas no controle de patógenos biotróficos do trigo. Summa Phytopathologica, v.44, n.2, p.132-136, 2018.

Danos na cultura do trigo estão associados a ferrugem da folha (Puccinia triticina) e ao oídio (Blumeria graminis f. sp. tritici). O presente trabalho objetivou avaliar o efeito de fosfito de potássio e acibenzolar-S-metil isolados e/ou associados ao fungicida epoxiconazole + piraclostrobina no controle do oídio e da ferrugem da folha e no rendimento de grãos. Os experimentos foram delineados em bloco ao acaso, com quatro repetições constituídas por parcelas com 17 linhas de semeadura espaçadas em $0,17 \mathrm{~m}$, com dimensões de 2,89 $\mathrm{x}$ 5,0 m. A severidade do oídio e da ferrugem da folha foi avaliada em 10 folhas bandeira e em 10 plantas inteiras ao longo do ciclo de cultivo, avaliou-se também a produtividade. Com os dados de severidade calculou-se a área abaixo da curva de progresso das doenças. Não houve efeito das aplicações de fosfito isolado ou associado ao fungicida epoxiconazole + piraclostrobina em diferentes épocas sobre o oídio. O acibenzolar-S-metil controlou em média cerca de $70 \%$ do oídio. Os fosfitos isolados e/ou associados ao fungicida tiveram efeito sobre a ferrugem da folha reduzindo a severidade em 59 e $62 \%$ em relação à testemunha. Aplicações de fosfitos isolados não afetaram os componentes de rendimento.

Palavras-chave: Indução de resistência, Blumeria graminis f. sp. tritici, Puccinia triticina, Triticum aestivum, época de aplicação, ferrugem da folha e oídio.

Wheat (Triticum aestivum $\mathrm{L}$.) is highly sensitive to disease-causing agents such as mycoplasmas, fungi, bacteria, viruses, and nematodes. Among them, the most damaging pathogens are those causing powdery mildew (Blumeria graminis f. sp. tritici) E. (Marchal) and wheat leaf rust (Puccinia triticina (Erikss)) (19).

Powdery mildew is the first endemic leaf disease that occurs in wheat crops in cold and wet regions in Brazil, particularly in the southern region and irrigated crop systems in the west-central and southeastern regions. Even during periods of favorable weather conditions for wheat crop cultivation, grain yield reduction of up to $62 \%$ may occur because of the disease (19).

Leaf rust is one of the major foliar diseases that affect the crop. Damage from $P$. triticina epidemics depend on the growth stage of the wheat plant, the susceptibility of the cultivar to the infectious agent, the virulence of the physiological race, and the environmental conditions (20). Fernandes \& Picinini (8) evaluated the cultivar BR 34 during the
1994-1995 seasons in Passo Fundo region and reported significant damage to the wheat crop and $80 \%$ reduction in grain yield.

The most efficient method of disease control is based on the genetic resistance of commercial wheat cultivars; however, because pathogens undergo physiological adaptations, the efficiency of this practice declines after a number of crop cycles. Cultivars with resistance genes exert selection pressure, leading to changes in the pathogen's genes that enable it to infect cultivars that were previously considered resistant (17). As a result, chemical control remains the most widely used and recommended disease-control practice $(6,16)$. However, chemical control requires a number of technical recommendations, such as time of application, amount of product to be applied, weather conditions for application, and preparation of the equipment, without which the farmer's investment in chemical control may become a financial and environmental burden. For these reasons, the development of new pest-control alternatives is important. 
Thus, several authors consider the use of induced resistance in integrated pest management a promising approach $(4,15,24)$. Resistance induction has been developed in the agrochemical industry by using alternative products, such as phosphite-based foliar fertilizers.

The action of phosphites on fungi may occur directly or by activation of the plant defense mechanisms, such as stimulation of phytoalexin production $(11,22)$. Phosphite application induces an immediate response from the plant against the pathogen (11). Several studies conducted in Brazil have reported the efficiency of using phosphites, either alone or with other products, for a number of diseases, including downy mildew in onion (24), yellow and brown spot disease in wheat (18), and powdery mildew and Asian soybean rust in soybean crops (21).

The present study evaluated the effects of potassium phosphite and acibenzolar-S-methyl (ASM) alone and combined with the fungicides epoxiconazole + pyraclostrobin applied during different periods for the control of powdery mildew and leaf rust in wheat, as well as the effects of treatments on the crop yield.

\section{MATERIALS AND METHODS}

The experiments were conducted in the municipalities of Arapoti and Tibagi, in the region of Campos Gerais, Paraná State. Cfa and $\mathrm{Cfb}$ are the predominant climates in the municipalities of Arapoti and Tibagi, respectively (13). According to Embrapa (7), the soil at that region is classified as typical dystrophic Red Latosol, featuring a clayey texture and slightly undulating terrain relief (5-8\%).

Sowing was conducted in a no-tillage system directly through the corn stover. In Arapoti, a population of 350 plants $\mathrm{m}^{-2}$ (cultivar BRS 2018) was sowed on May 30, 2007. Similarly, in Tibagi, a population of 350 plants $\mathrm{m}^{-2}$ (cultivar Supera) was sowed on June 5, 2007.

The treatments shown in Table 1 refer to both experiments. Application was performed with the aid of knapsack sprayer (Herbicat, Catanduva, Brazil), equipped with an XR110.02 VS six flat fan nozzle with a $0.5-\mathrm{m}$ spacing nozzle and a spray volume of $135 \mathrm{~L} \mathrm{ha}^{-1}$, at a constant pressure of $159 \mathrm{kPa}$, with compressed carbon dioxide. The products were sprayed during different growth stages according to the scale proposed by Zadoks et al. (25).

Experimental design was in randomized blocks with four replicates. Each experimental unit consisted of $2.89 \times 5.0 \mathrm{~m}$ plots composed of 17 rows spaced at $0.17 \mathrm{~m}$ from one another, comprising a total area of $14.45 \mathrm{~m}^{2}$ and a usable area of $6.8 \mathrm{~m}^{2}$.

Weekly severity assessments of powdery mildew and wheat leaf rust were performed, starting from the tillering stage (beginning of July) to the grain formation stage (end of September). The assessments were performed by using 10 flag leaves and 10 whole plants. The percentage of damaged leaf area was determined with the aid of a diagrammatic scale (1) for each plot. The area under the disease progress curve (AUDPC) was calculated by utilizing the disease severity data from the flag leaves and whole plants, adopting the equation proposed by Shaner \& Finny (23) described below:

$$
\mathrm{AUDPC}=\sum_{i=1}^{n}\left[\mathrm{Y}_{i+1}+\mathrm{Y}_{i} / 2\right]^{*}\left[\left(\mathrm{~T}_{i+1}-\mathrm{T}_{i}\right)\right]
$$

where: Yi: disease severity at time of evaluation $\mathrm{i}(\mathrm{i}=1, \mathrm{n})$; $\mathrm{Yi}+1$ : disease severity in the evaluation period $i+1$; Ti: time of evaluation $i$, which is generally considered the number of days after the emergence of plants; $\mathrm{Ti}+1$ : evaluation time $\mathrm{i}+1$; $\mathrm{N}$ : number of observations.

For the assessment of yield components, all plants within one meter in the central rows of each plot were removed. The following data were recorded: number of plants $\mathrm{m}^{-2}$, number of tillers per plant, plant height, ear height, number of spikelets, number of grains per spikelet, number of grains per ear, and number of ears per meter and per hectoliter weight (except for the experiment conducted in Arapoti).

Wheat was manually harvested within the usable area of plots. Nine rows $(4 \mathrm{~m})$ were harvested, totaling $6.8 \mathrm{~m}^{2}$ harvested area in Tibagi on October 9 and in Arapoti on October 10, 2007. Grain yield was expressed as $\mathrm{kg} \mathrm{ha}^{-1}$, and the standard moisture content was set to $13 \%$.

The obtained data were subjected to the analysis of variance (ANOVA) F test. Comparison of averages, when ANOVA was significant, was performed according to Tukey's test at $5 \%$ probability level. Prior to analysis, the disease severity percentage data were subjected to the arcsine square root transformation divided by 100 (2).

\section{RESULTS AND DISCUSSION}

The AUDPC for powdery mildew in the flag leaf and whole plant (Table 2) revealed that treatment with ASM controlled the disease, regardless of the addition of fungicide. The AUDPC was statistically similar for treatments with ASM alone and with fungicide, demonstrating the curative effect of ASM on powdery mildew.

Different results were obtained by Dallagnol et al. (5), who noted an increased efficiency in the control of foliar soybean diseases only when ASM was applied before the appearance of symptoms of the disease and when ASM was applied with the fungicide difenoconazole at stages $\mathrm{R}_{3}$ and $\mathrm{R}_{4}$

The fungicide reduced the AUDPC for powdery mildew in the flag leaf but did not differ statistically from the treatments that received potassium phosphite and potassium phosphite + fungicide. Thus, it had the same curative effects as ASM. Santos et al. (20) found that epoxiconazole + pyraclostrobin, both alone or with potassium phosphite and ASM, reduced the AUDPC for leaf spots on wheat.

The treatments that received potassium phosphites ( 2 and 3 ) did not differ statistically from control in relation to the AUDPC for the flag leaf. Among the treatments that received phosphite, treatment 4 showed the highest disease control, similar to treatments that received ASM (6 and 7). For the AUDPC of the whole plant, treatment 2 had the same effect as control. Conversely, treatments 3 and 4 showed intermediate disease control, compared to control and the treatment that received one fungicide application (treatment 5). Hukkanen et al. (12) found few symptoms of Peronospora sparsa in raspberry plants treated with the fungicide tolylfluanid and ASM. The authors also observed that fosetyl-Al, Phostrol (phosphoric acid salts), and Phosfik (phosphorous acid) provided moderate protection to the plants.

The low severity of powdery mildew did not interfere with productivity. The yield components of wheat in experiment 1 (data not displayed) were statistically similar to those of control. The treatment that resulted in the highest crop yield only received application of epoxiconazole + pyraclostrobin (Table 2 ), and the yield was statistically different from that of control and the treatment that received only Phosphite (treatments 1 and 2, respectively). Other treatments provided intermediate yield when compared to control and treatments in which fungicide was applied. No decreased and/or increased yield was observed when the fungicide was added to ASM. Conversely, Mckenzie (14) stated that when ASM is included as an integral part of the crop management program, it not only improves disease control but also increases crop yield. The benefits of such a management program can 
Table 1 Treatment, time of application, and active ingredient (a.i.) used in the control of powdery mildew, cultivar BRS 208, Arapoti - PR (Experiment 1), and in the control of leaf rust, cultivar Supera, Tibagi - PR (Experiment 2), 2007 Season.

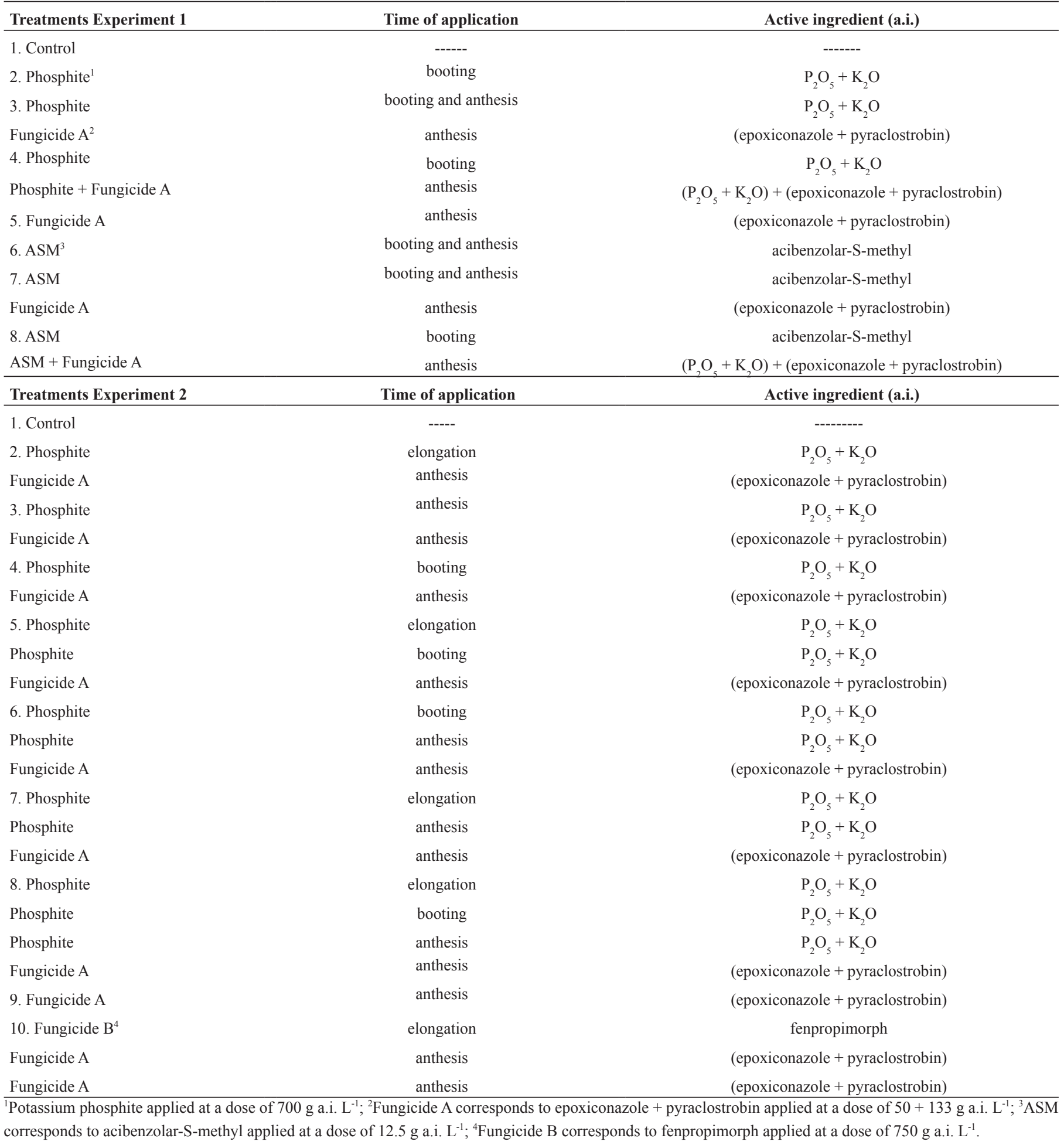

be demonstrated for a number of crops, such as tomato.

The AUDPC for leaf rust disease in flag leaves and whole plants showed that all treatments differed significantly from control (Table 3).

Treatment 10 received three fungicide applications and displayed a lower AUDPC in the flag leaf and whole plant (Table 3). Except for treatment 3 , other treatments that received one, two, or three applications of phosphite $(2,4,5,6,7$, and 8$)$ and the treatment that received only one fungicide application (9) produced similar effects. These treatments $(2,3,4,5,6,7,8$, and 9) lowered the AUDPC in flag leaves and whole plants, although they were not effective.

The productive potential of Supera cultivar ranges between 3,500 and 7,000 $\mathrm{kg} \mathrm{ha}^{-1}(17)$. This yield output was observed only for treatment 
Table 2. Area under the powdery mildew progress curve (AUDPC) in the flag leaf and whole plant, and crop yield (YIELD) affected by potassium phosphite alone and with fungicide, in the wheat cultivar BRS 208. Arapoti - PR, 2007 Season.

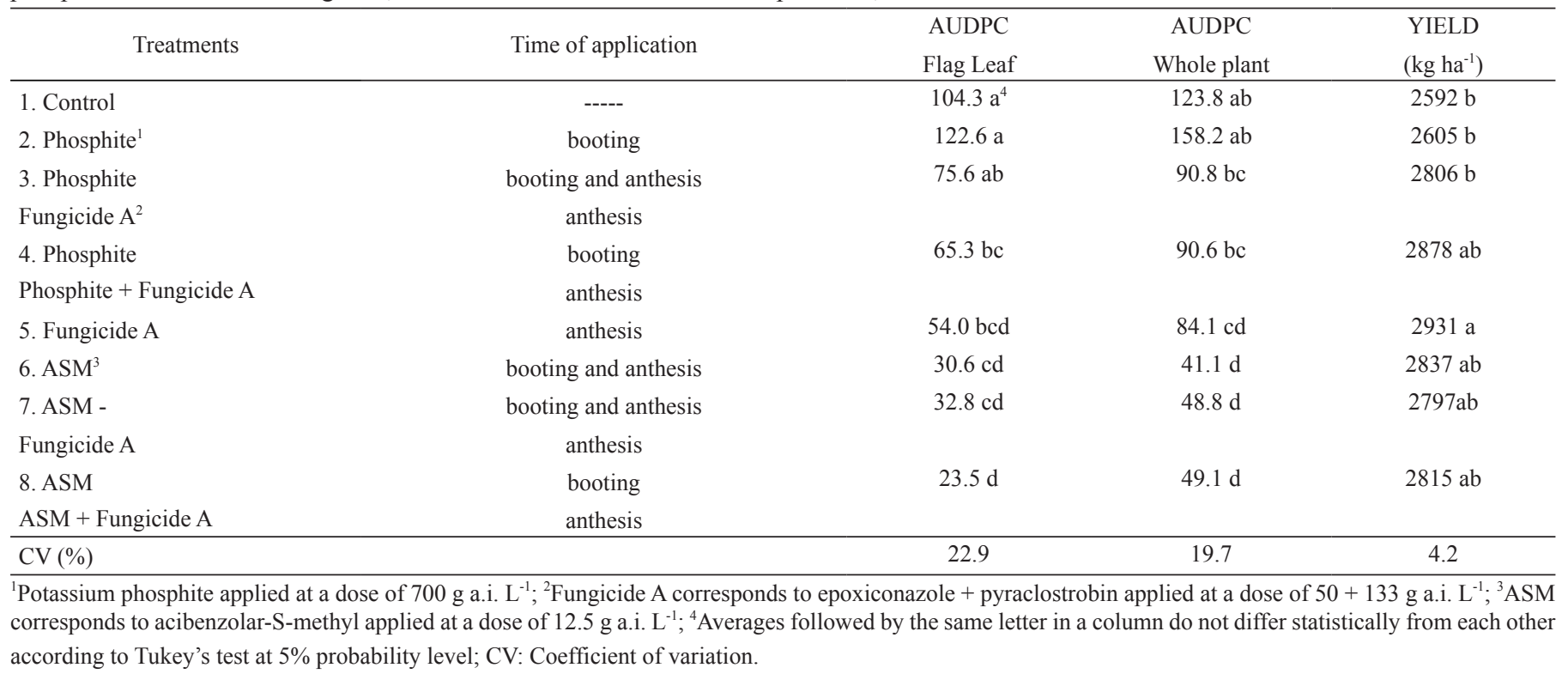

Table 3. Area under the leaf rust progress curve (AUDPC) in the flag leaf and whole plant, hectoliter weight (HW) and yield (YIELD) affected by phosphite alone and with fungicides in the wheat crop of the cultivar Supera. Tibagi - PR, 2007 Season.

\begin{tabular}{|c|c|c|c|c|c|}
\hline Treatments & Time of application & $\begin{array}{c}\text { AUDPC } \\
\text { Flag Leaf }\end{array}$ & $\begin{array}{c}\text { AUDPC } \\
\text { Whole plant }\end{array}$ & HW & $\begin{array}{r}\text { YIELD } \\
\left(\mathrm{kg} \mathrm{ha}^{-1}\right)\end{array}$ \\
\hline 1. Control & & $1739 a^{4}$ & $1683 \mathrm{a}$ & $78.1 \mathrm{c}$ & $2554 \mathrm{~b}$ \\
\hline Fungicide $\mathrm{A}^{2}$ & anthesis & & & & \\
\hline 3. Phosphite & anthesis & $1184 \mathrm{~b}$ & $1193 \mathrm{~b}$ & $79.9 \mathrm{ab}$ & 2944 b \\
\hline Fungicide A & anthesis & & & & \\
\hline 5. Phosphite & elongation & $994 \mathrm{bc}$ & $1055 \mathrm{bc}$ & $79.8 \mathrm{~b}$ & $3043 \mathrm{~b}$ \\
\hline Phosphite & booting & & & & \\
\hline Fungicide A & anthesis & & & & \\
\hline Phosphite & anthesis & & & & \\
\hline Fungicide A & anthesis & & & & \\
\hline 8. Phosphite & elongation & $1117 \mathrm{bc}$ & $1127 \mathrm{bc}$ & $80.4 \mathrm{ab}$ & $2877 \mathrm{~b}$ \\
\hline Phosphite & booting & & & & \\
\hline Phosphite & anthesis & & & & \\
\hline Fungicide A & anthesis & & & & \\
\hline 9. Fungicide A & anthesis & $1110 \mathrm{bc}$ & $1109 \mathrm{bc}$ & $80.3 \mathrm{ab}$ & $2883 \mathrm{~b}$ \\
\hline 10. Fungicide $B^{3}$ & elongation & $71 \mathrm{~d}$ & $180 \mathrm{~d}$ & $81.3 \mathrm{a}$ & 4067 a \\
\hline Fungicide A & booting & & & & \\
\hline
\end{tabular}

${ }^{1}$ Potassium phosphite applied at a dose of $700 \mathrm{~g}$ a.i. $\mathrm{L}^{-1} ;{ }^{2}$ Fungicide A corresponds to epoxiconazole + pyraclostrobin applied at a dose of $50+$ $133 \mathrm{~g}$ a.i. $\mathrm{L}^{-1}$; ${ }^{3}$ Fungicide B corresponds to fenpropimorph applied at a dose of $750 \mathrm{~g}$ a.i. $\mathrm{L}^{-1}$; ${ }^{4}$ Averages followed by the same letter in a column do not differ statistically from each other according to Tukey's test at 5\% probability level; CV: Coefficient of variation. 
10, which received three applications of fungicides (Table 3). Other treatments showed no effect in preventing plant damage and, as a result, the crops exhibited low productivity.

An increase was observed in the total number of plants for treatments 5, 8, 9 and 10, considering the yield components in experiment 2 (data not shown). Except for the number of ears per meter in treatment 3, and hectoliter weight in treatment 1 , all treatments showed an increase in the values of these parameters. Other yield components were not affected by the treatments (Table 3 ). Several authors reported different responses of wheat cultivars to chemical treatment $(3,9,10)$; the most susceptible cultivars, especially to leaf rust, are those that often have the greatest gains in productivity after fungicide application. As observed by Navarini et al. (16) in an experiment conducted with various cultivars, the cultivar OR 1 (susceptible to leaf rust) displayed the greatest difference in grain yield when compared to control because of the greater effectiveness of the chemical treatment.

Application of phosphite, either alone or with fungicides, was inefficient in controlling powdery mildew and leaf rust in wheat and did not increase the crop productivity. Conversely, ASM alone or with a fungicide was effective in controlling powdery mildew. Applications conducted during booting and anthesis reduced the severity of powdery mildew and contributed to increased crop productivity. The fungicides fenpropimorph and epoxiconazole + pyraclostrobin were efficient in controlling leaf rust and increased the crop productivity after three applications during elongation, booting, and anthesis.

\section{REFERENCES}

1. Azevedo, A.L.S. Manual de quantificação de doenças de plantas. São Paulo: Ed. do autor, 1997. 114p.

2. Banzatto, D.A.; Kronka, S.N. Experimentação agrícola. Jaboticabal: Funep, 2006. 235p.

3. Barros, B.C. Avaliação da resistência varietal e da resposta de cultivares de trigo (Triticum aestivum $\mathrm{L}$.) ao controle químico de oídio, mancha marrom e ferrugem da folha. 1988. 122f. Tese (Doutorado em Fitopatologia) - Escola Superior de Agricultura "Luiz de Queiroz", Universidade de São Paulo, Piracicaba.

4. Brackmann, A.; Fabiano, R.; Gieh, H.; Sestari, I.; Steffens, C.A. Fosfitos para o controle de podridões pós-colheita em maçãs 'Fuji' durante o armazenamento refrigerado. Ciência Rural, Santa Maria, v.34, n.4, p.1039-1042, 2004.

5. Dallagnol, L.J.; Navarini, L.; Ugalde, M.G.; Balardin, R.S.; Catelam, R. Use of Acibenzolar-S-Methyl to control foliar diseases of soybean. Summa Phytopathologica, Botucatu, v.32, n.3, p.255-259, 2006.

6. Debona, D.; Favera, D.D.; Corte, G.D.; Domingues, L.C.; Balardin, R.S. Controle químico da ferrugem da folha em cultivares de trigo submetidas a diferentes níveis de adubação nitrogenada. Revista da Faculdade de Zootecnia, Veterinária e Agronomia, Uruguaiana, v. 16, n.1, p.52-65, 2009.

7. Embrapa. Centro Nacional de Pesquisa de Solos. Sistema brasileiro de classificação de solos. Rio de Janeiro: Embrapa Solos, 1999.

8. Fernandes, J.M.C.; Picinini, E.C. Controle da ferrugem da folha e das manchas bronzeada da folha de trigo pelo uso de fungicidas em tratamento de sementes. Fitopatologia Brasileira, Brasília, DF, v.26, n.1, p.131-131, 2001.

9. Fernandes, J.M.C.; Vieira, J.C.; Picinini, E.C.; Sartori, J.F.; Prestes, A.M. Resposta de cultivares de trigo ao tratamento com fungicidas. In: Reunião Nacional de Pesquisa de Trigo, 09, 1980, Porto Alegre. Anais. Passo Fundo: Embrapa, Cnptrigo, 1980. p.56-75.

10. Giordani, N.A.; Neto, N. Resposta de cultivares e linhagens de trigo a fungicidas em 1985. In: Reunião Nacional de Pesquisa de Trigo, 14., 1986, Londrina. Resumos. Londrina: Iapar, 1986. p.88.

11. Guest, D.I.; Grant, B.R. The complex action of phosphonates as antifungal agents. Biological Review, Cambridge, v.66, s.I, p.159-187, 1991.

12. Hukkanen, A.; Kostamo, K.; Karenlampi, S.; Kokko, H. Impact of Agrochemicals on Peronospora sparsa and Phenolic Profiles in Three Rubus arcticus Cultivars. Journal Agricultural Food Chemistry, Washington, v.56, n.3, p.1008-1016, 2008

13. Iapar. Cartas climáticas do estado do Paraná. Londrina, 2000. Available in: <www.iapar.br/Sma/Cartas_Climaticas >. Accessed on: 24 Oct. 2008.

14. Mckenzie, D. The development of acibenzolar-S-methyl (ASM) for use in crop management. Fitopatologia Brasileira, Brasília, DF, v.26, suplemento, p.256-256, 2001.

15. Nascimento, A.R.; Fernandes, P.M.; Rocha, M.R.; Silva, E.A. Fontes de fosfito e acibenzolar-S-metil no controle de doenças e produtividade o tomateiro. Bioscience Journal, Uberlândia, v.24, n.1, p.53-59, 2008.

16. Navarini, L.; Dallagnol, L.J.; Rocha, M.R.; Silva, E.A. Controle químico das doenças foliares em cultivares de trigo. Revista Faculdade de Zootecnia Veterinária e Agronomia, Uruguaiana, v.12, n.1, p.34-43, 2005.

17. Niewoehner, A.S.; Leath, S. Virulence of Blumeria graminis f. sp. tritici on winter wheat in the eastern United States. Plant Disease, Saint. Paul, v.82, n.1, p.64-68, 1998.

18. Or Sementes. Cultivares OR 2001: para quem busca lucratividade e segurança. Passo Fundo, 2001. Available in: <http://www.orsementes.com.br/ prod.htm>. Accessed on: 29 May. 2008.

19. Reis, E.M.; Casa, R.T. Doenças dos cereais de inverno: diagnose, epidemia e controle. Lages: Graphel, 2007.

20. Santos, H.A.A.; Dalla Pria, M.; Silva, O.C.; May de Mio, L.L. Controle de doenças do trigo com fosfitos e acibenzolar-s-metil isoladamente ou associados a piraclostrobina + epoxiconazole. Semina, Londrina, v.32, n.2, p.433-442, 2011.

21. Silva, O.C.; Santos, H.A.A.; Dechamps, C.; Dalla Pria, M.; May de Mio, L.L. Fontes de fosfito e acibenzolar-S-metílico associados a fungicidas para o controle de doenças foliares na cultura da soja. Tropical Plant Pathology, Brasília, DF, v.38, n.1, p.072-077, 2013.

22. Smillie, R.; Grant, B.R.; Guest, D. The mode of action of phosphite: evidence for both direct and indirect modes of action on three Phytophthora spp. in plants. Phytopathology, Saint Paul, v.79, n.9, p.921-926, 1989.

23. Shaner, G.; Finney, R.E. The effects of nitrogen fertilization on the expression of slow-mildwing in knox wheat. Phytopathology, Saint Paul, v.67, n.8, p.1051-1055, 1977.

24. Wordell Filho, J.A.; Martins, D.A.; Stadnik, M.J. Aplicação foliar de tratamentos para o controle do míldio e da podridão-de-escamas de bulbos de cebola. Horticultura Brasileira, Brasília, DF, v.25, n.4, p.544-549, 2007.

25. Zadoks, J.C.; Chang, T.T.; Konzak, C.F. A decimal code for the growth stages of cereals. Weed Research, Oxford, v.14, p.415-421, 1974. 